\title{
How to make housing sustainable? The Dutch experience ${ }^{\dagger}$
}

\author{
Hugo Priemus \\ OTB Research Institute for Housing, Urban and Mobility Studies, Delft University of Technology, \\ JA Delft 2629, The Netherlands; e-mail: h.priemus@tbm.tudelft.nl \\ Received 22 July 2003; in revised form 20 July 2004
}

\begin{abstract}
Sustainable housing has been a major topic of national policy in the Netherlands for fifteen years. The author argues that sustainable housing is a badly defined concept, both in scientific literature and in policy documents. The Dutch government has never indicated how the sustainability of housing could be measured, or realized a zero measurement, which would enable researchers to evaluate environmental policies to promote sustainable housing properly. A narrow definition of sustainability is adopted, whereby the author concentrates on the ecological dimensions of the concept of 'sustainability': the environmental impact on the greenhouse effect; the quality of air, water, and soil; noise nuisance; stench; the stock of nonrenewable materials; and biodiversity. An overview of ways in which the sustainability of housing can be measured is given and the use of a multivariate yardstick advocated. A set of recommendations is presented for politicians and public officials about the way in which sustainable housing can be promoted, and a research agenda on sustainability in housing presented. The author concludes by pointing out the analogy between the Dutch government's policy to promote sustainable housing and the story of the emperor's new clothes. The moral is that it is better to acknowledge that we do not know essential things about sustainable housing than simply to 'believe' in it.
\end{abstract}

\section{Introduction}

In the broad literature on sustainable housing, 'sustainable' seems to mean everything. It is about ecology and the environment, but it is more than technology: it is also about social cohesion, community sustainability, citizen participation, and lifestyles. Sustainability is profit, people, and planet at the same time; it seems to mean something like happiness.

Take, for example, the way in which Lawrence (2000) develops the concept of sustainability as an axiom and a challenge. He associates sustainability with, amongst other things, participatory design processes and planning practices, the economy, the environment and health, nature conservation in urban areas, ecological dimensions, compact human settlements, and livable cities.

This is not my approach in this paper. I define sustainable housing in a narrower sense: housing with a minimum of negative impacts on the environment. Sustainability is defined in this paper in an ecological sense: such as the development of an ecosensitive housing concept (Bhatti, 2001, page 39). This paper deals with national policies aimed at promoting sustainable housing. It takes the Netherlands as a case where, for fifteen years, there has been a national government commitment to promote sustainable building and housing.

The Netherlands' first National Environmental Policy Plan was published in 1989, and sustainability has been high on the political agenda ever since. Various policy documents have considered the topics of sustainable building and sustainable housing. Current building legislation, in the form of the Bouwbesluit or 'building directive', 
devotes considerable attention to the requirements of good environmental management and energy efficiency. In 1990, 'the environment' became the responsibility of a specific minister, namely the Minister of Housing, Spatial Planning and the Environment. In 2002 the political responsibility for environmental matters devolved to a state secretary when Pieter van Geel took on the portfolio of 'green policies'.

This contribution deals first with the notion of sustainable housing: what makes housing sustainable? In section 2 sustainable housing is contextualised scientifically and politically. Section 3 gives an overview of ways in which the sustainability of housing can be measured. I argue that only a multivariate yardstick makes sense. In section $4 \mathrm{I}$ pose the question of whether Dutch policy to promote sustainable housing has actually produced any results. The disappointing conclusion is that this question cannot be answered. Section 5 presents a set of recommendations for elected politicians and public officials about the way in which sustainable housing can be promoted. Are there any ideas about how an effective and efficient public policy could be developed for promoting sustainable housing? Finally, I make some concluding remarks and present some proposals for building blocks for a research agenda on sustainable housing.

\section{What makes housing sustainable?}

Like most of my colleagues, I apply the Brundtland Report definition of 'sustainability': in the report Our Common Future (World Commission on Environment and Development, 1987), 'sustainable development' is defined as development that meets the needs of the present without compromising the ability of future generations to meet their own needs. Presumably, the central consideration of the Brundtland Report is whether the planet is capable of sustaining its inhabitants. McMichael (1993) speaks of 'planetary overload' in the same context.

When we apply this approach to the concept of 'sustainable housing' we find its global orientation to be inadequate. Sustainable development takes place on different scales (Dommen, 1993; Hatfield Dodds, 2000; Rotmans, 2003, page 24). The quality and availability of water, soil pollution, and noise nuisance all play a role at local and regional levels. So what matters in this context is more the local and regional capacity, or the resilience of the catchment basin. When we speak of 'sustainable housing' we mean housing that is geared to meeting the needs of the current residents without compromising the ability of future generations of residents to meet their own needs. To put it bluntly, we must not saddle posterity, or other parts of the world, with our unpaid bills.

The definition of 'sustainability' is often stretched somewhat in discussions on the theoretical and practical aspects of sustainable housing. In addition to stressing the ecological dimension - as in the case of the Brundtland Report - it is extended to social and economic dimensions (Lawrence, 2000; Polèse and Stren, 2000; Redclift, 1989). Without playing down the importance of social and economic factors, in this paper I will concentrate on the ecological and environmental dimensions of sustainability. The metaphor of the 'ecological footprint' (Wackernagel and Rees, 1996) will be applied to describe the environmental impacts. 'Sustainable housing' is defined as housing with a minimum of negative environmental impacts in terms of climate change (greenhouse effect); the quality of air, water, and soil; noise; stench; the stock of nonrenewable materials; and biodiversity. 


\section{How can we measure the sustainability of housing?}

\subsection{Life cycle and the 'ecodevice' model}

It is not easy to measure sustainability. Theoreticians and practical experts run into huge problems when attempting to measure the environmental impact of residential property. The environmental impact of residential property will depend on the lifecycle phase of the building itself, and the construction components (Guinée et al, 2002; ISO, 1997). See figure 1.

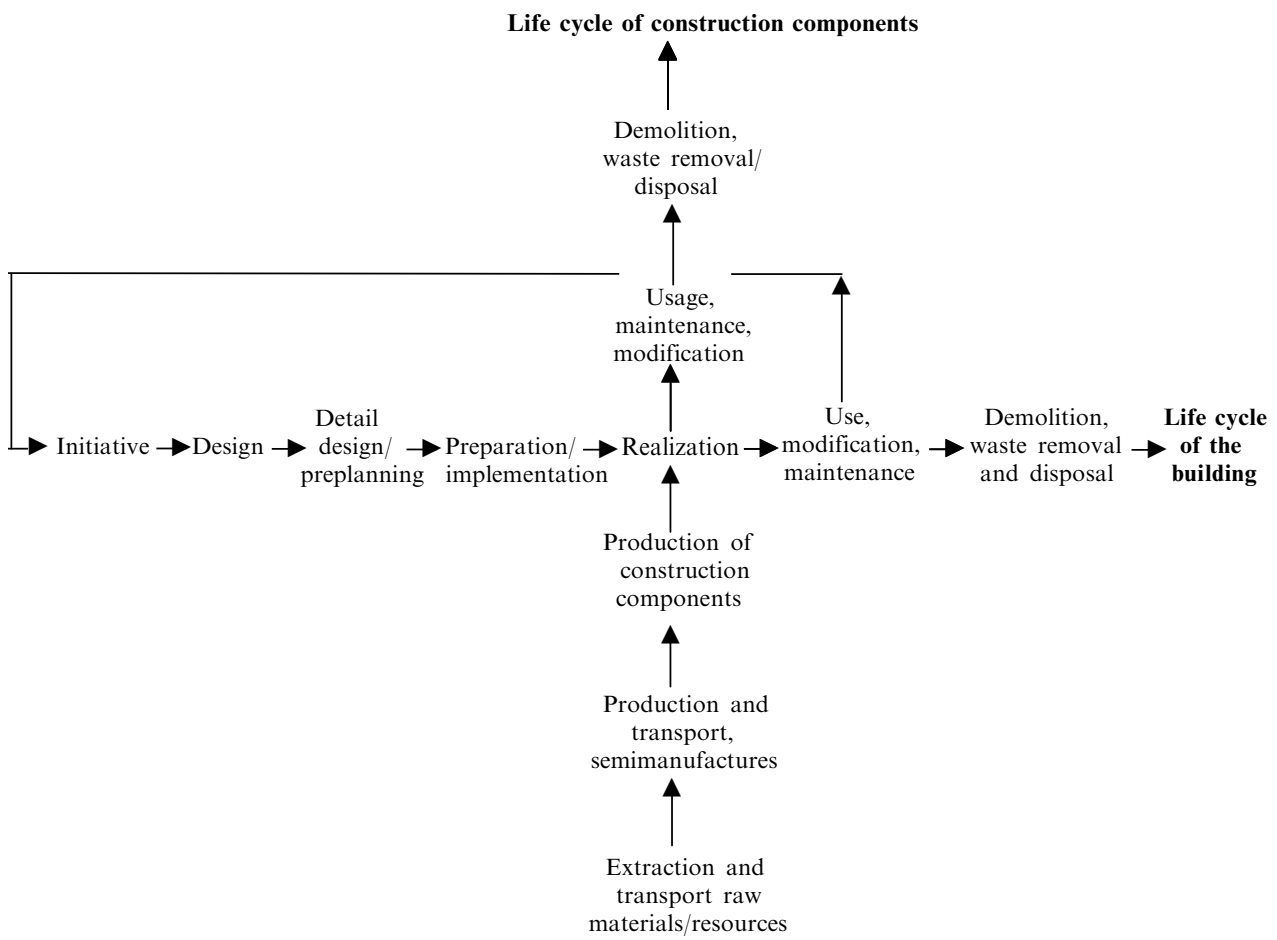

Figure 1. The life cycle of buildings (source: Blaauw, 2001, page 40; Dicke, 2000).

The life-cycle costs of housing can be derived from the various 'flows' during the different stages of the life cycle of the residential unit. The 'ecodevice' model (see figure 2) offers a simplified representation of material usage and wear.

In addition to the flows into and out of the system, two 'protective' functions - resistance and retention - can be discerned, serving to influence both incoming and outgoing flows. These protective functions determine the environmental efficiency of the system.

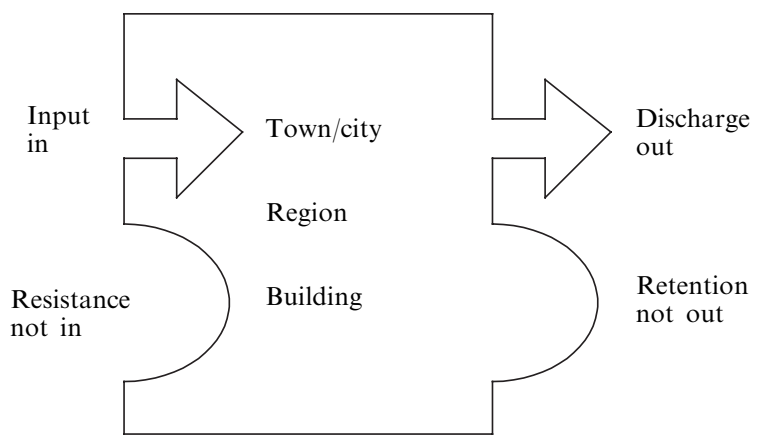

Figure 2. The 'ecodevice' model (source: Duijvestein, 1997). 
In the case of new buildings the incoming flow is determined by the construction materials, the interior fittings and furnishings, replacement materials used over time, and energy and water consumed during everyday use and during the maintenance of the property throughout its life cycle. Here, we can identify energy flows, material flows, and water flows. Each type of flow is considered in brief in the following sections, which draw heavily on Blaauw (2001).

\subsection{Energy flows}

The energy consumption of the residential sector accounts for some $18 \%$ of the Dutch national total (Ministry of Housing, Spatial Planning and the Environment, 1997). A small proportion of this is material-related energy and must therefore be included in a consideration of the material flows. However, by far the greatest proportion of the energy flow is accounted for by the residents' use of the property. For the existing housing stock, this type of energy consumption may be further broken down into: $76 \%$ for heating, $21 \%$ for hot water, and 3\% for lighting (Blaauw, 2001, page 43). 'Appliance-related functions' are functions which pertain to the use of household appliances, such as cookers, washing machines, television sets, radios, vacuum cleaners, and air-conditioning systems. Figure 3 shows the typical breakdown of residential energy consumption.

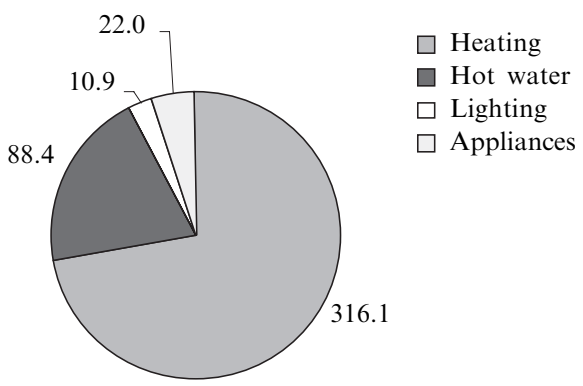

Figure 3. Average residential energy consumption by function (PJ per year) (source: van Arkel et al, 1999; Novem, 1998; Blaauw, 2001, page 44).

In the Netherlands, electricity is generated largely from the combustion of fossil fuels $-68 \%$ gas and 29\% coal-with the remaining 3\% derived from nuclear fuels (ECN, 2000). The government wishes to bring about a shift towards more sustainable energy sources, such as those listed in table 1.

When considering the energy consumption of the residential sector, the heat balance of homes is an important aspect (figure 4). The heat balance of a residential property indicates where most energy flow is lost, and hence ways in which energy efficiency can be improved.

Table 1. Types of sustainable energy (source: Blaauw, 2001, page 44).

Tidal energy

Wave energy

Ocean current energy

Water energy (hydroelectric generation)

Wind energy

Photovoltaic (PV) energy

Solar-thermic energy

Residual heat

Energy derived from the combustion of household waste (a minimum of 50\% biomass by volume) Energy derived from purpose-produced biomass

Energy derived from the gas released by the process of anaerobic fermentation in landfill sites Geothermic energy 


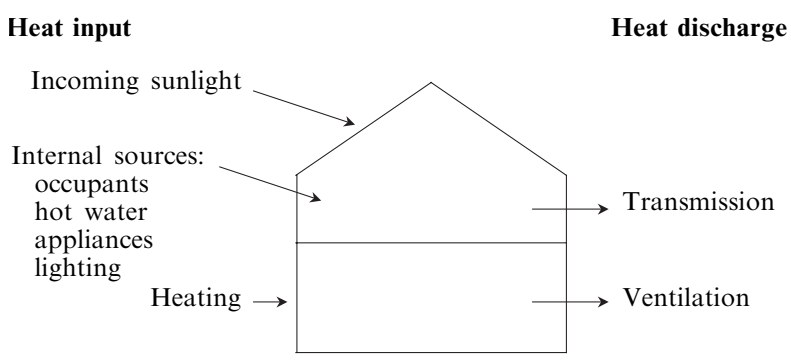

Figure 4. Heat balance of residential properties (source: Blaauw, 2001, page 46).

\subsection{Material flows}

By using the 'Ecoquantum' environmental assessment programme and a number of reference dwellings, it is possible to determine the environmental impact of residential properties in terms of the material flows involved. The Novem standard semidetached house weighs $233000 \mathrm{~kg}$; the Novem walkway-type apartment weighs $142000 \mathrm{~kg}$. Initial construction will account for $86 \%$ of the overall material flows during the lifetime of the building; the remaining $14 \%$ being consumed during maintenance and component replacement (Klunder, 2000). Figure 5 shows the material flows in the residential sector at housing-stock level.

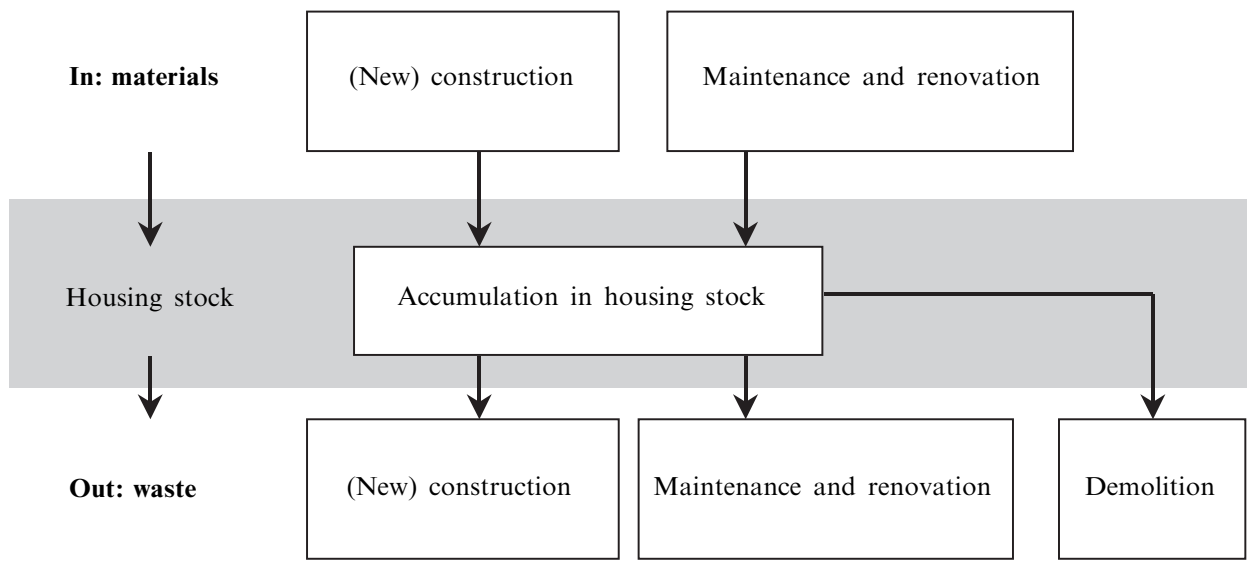

Figure 5. Material flows in the residential sector at housing stock level (source: Blaauw, 2001, page 52).

Housebuilding activities account for $19 \%$ of the total waste flow in the Netherlands, equivalent to approximately $3110 \mathrm{Kt}$ per annum. This can be broken down further into: $19 \%$ from the construction of new property, $46 \%$ from the renovation of existing property, and $35 \%$ from demolition. At present, just under $92 \%$ of the waste is reused, $7 \%$ is consigned to landfill sites, and the remainder is burnt (CBS and RIVM, 1999). Three categories of material can be identified here:

(1) nonrenewable resources (stone and stone derivatives, metals, plastics, glass);

(2) renewable resources (wood, fibres such as wool and flax, paper); and

(3) secondary resources (both renewable and nonrenewable).

Table 2 (see over) provides an indication of the material consumption of the reference unit (a bungalow with garden) during various phases of the life cycle. It is possible to reduce the material flows in the housing sector by means of the dematerialization of certain services, and by increasing recycling strategies. 
Table 2. Material consumption (in $\mathrm{kg}$ ) of the reference unit (a bungalow with garden) during various phases of the life cycle (source: Klunder, 2000; Blaauw, 2001, page 53).

\begin{tabular}{lrrr}
\hline Material & Life-cycle phase & & \\
\cline { 2 - 4 } & construction & replacement & maintenance \\
\hline Nonrenewable & & & \\
Stone/stone derivatives and substitutes & 138776 & 5142 & 622 \\
Sand & 10160 & 0 & 15240 \\
Glass & 420 & 825 & 0 \\
Metals $\quad 2126$ & 1174 & 0 \\
$\quad$ (of which heavy metals) & 239 & 202 & 42 \\
Plastic/acrylics & 598 & 425 & 47 \\
Paint & 15 & 19 & 53 \\
Glues and sealants & 722 & 96 & 0 \\
Renewable & & & 0 \\
Wood & 2470 & 1021 & 0 \\
Paper and pressed board & 153 & 338 & \\
Secondary & & & \\
Plaster & 4621 & 1766 & \\
\end{tabular}

\subsection{Water flows}

Residential property influences the water system through the consumption of water (in the Netherlands, water is provided via a process of natural filtration of groundwater from the dunes) and the discharge of waste water into the drainage system. A secondary influence is that exerted on the disposal of rainwater, which may be affected by artificial earthworks. In 1998 the average daily drinking-water consumption in the Netherlands was 1281 per person, or 3201 per household (Novem and Boom, 2000). Almost half of this drinking water was derived from groundwater sources, with domestic use accounting for some $10 \%$ of total groundwater abstraction and processing (Novem and Boom, 2000). Most drinking water is processed and supplied by waterproduction companies, and may be extracted either from groundwater or from surface water. In the home, the lavatory and the shower account for the greater part of consumption, followed by the washing machine and the kitchen tap.

Water consumption has risen markedly during the past ten years, largely because of the increase in the use of hot water from the tap. Drinking-water consumption may be limited by increasing the efficiency of equipment and physical infrastructure, by reducing losses due to leakage, and by substituting rainwater where the intended use does not call for the standard of purification associated with drinking water. However, the decisive factor will be the attitudes and practices of consumers themselves. It is increasingly recognised that technology can go only so far in improving the sustainability of housing: institutional arrangements are also important and must be optimised.

\subsection{Towards a multivariate yardstick}

When we try to establish the sustainability of a residential unit in one measurement we run into a whole barrage of difficulties. There is very little point in bundling the consumption of energy and the diverse materials along with water, stench, and noise nuisance in one figure. Many authors now agree (Curwell and Cooper, 1998, Kuik and Verbruggen, 1991; Mitchell, 2000) that it would be more logical to use a multivariate yardstick that would offer a 'sustainability profile' for the dwelling. This is illustrated by figure 6 on the sustainable planning of land-use activity, subdivision, and housing-SPLASH (BEICT, 2002). 


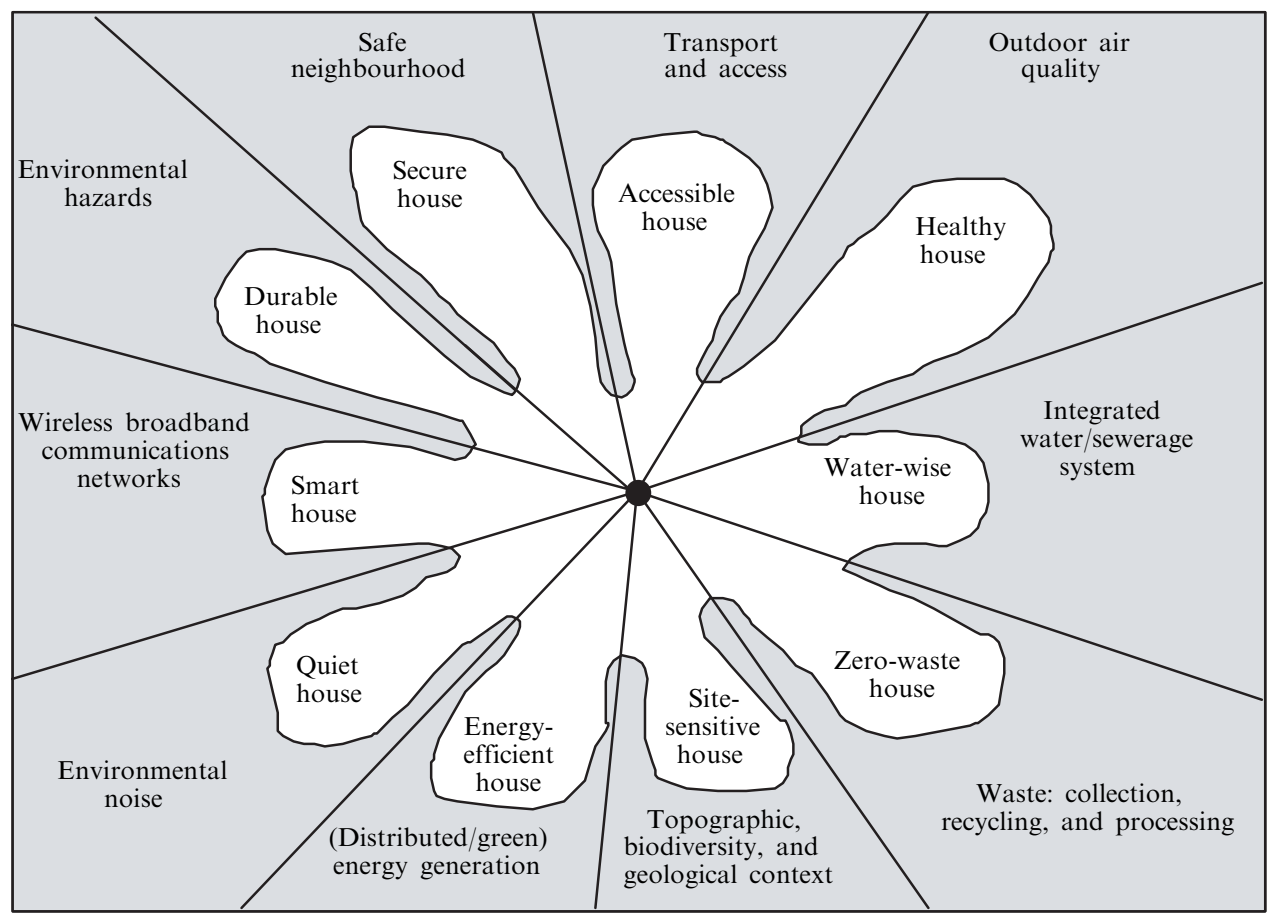

Figure 6. SPLASH - 'Sustainable Planning of Land Use Activity, Subdivision and Housing'.

The sustainability profile would be a combined measurement, reflecting the consumption of fossil-fuel energy, nonrenewable materials, and water; and the negative environmental impacts (greenhouse effect; quality of air, water, and soil; noise nuisance; stench; and biodiversity) that arise during the new building developments and/or the annual use of the dwelling. This last aspect is particularly dependent on the living patterns of the residents and the practices of the housing manager.

\section{Has Dutch policy to promote sustainable housing actually produced results?}

Has the political attention to sustainable building and sustainable housing over the past fifteen years in the Netherlands actually produced results? Recent studies (Blaauw, 2001; Klunder, 2002a; 2002b; Sunikka and Boon, 2002) suggest that the results are modest, as the main focus was on the manner in which new buildings are constructed. The regulations for new buildings have been tightened somewhat, particularly with regard to energy efficiency (Beerepoot, 2002; Sheridan, 2001). However, construction activities in recent years have tended to concentrate on owner-occupied housing, particularly single-family units. These homes are relatively large and, in absolute terms, do not represent any spectacular environmental savings. The so-called 'rebound effect' means that occupants simply modify their behaviour, thus negating the beneficial effects of the measures that developers and architects incorporate (Hertz, 1996). For example, a very well-insulated house runs the risk of overheating in summer, whereupon residents may make greater use of air-conditioning systems. In cases where the developer or property manager focuses solely on environmental gains - perhaps incorporating some advanced form of balanced ventilation-health hazards could arise if the ventilation systems are not properly maintained and the grills become clogged (Hasselaar, 2001). 
It should be noted that, to date at least, environmental measures have been concentrated on new construction: the environmental and energy efficiency of the existing stock has failed to keep pace (Quist and van den Broeke, 1994; Sunikka and Boon, 2002). In many urban districts, substantial sections of the housing stock are in need of major restructuring (van Kempen and Priemus, 1999; Kruythoff and Haars, 2002) and hence present yet another challenge for the proponents of sustainable building.

In effect, no serious attempts have been undertaken to ascertain the effectivenesslet alone the efficiency - of the national government policy to promote sustainable housing. But this is no easy task. Strictly speaking, what needs to be ascertained is the environmental impact of new housing development and the management and use of the housing stock with and without government regulations. There is no zero line for the environmental impacts of sustainable housing. A distinction needs to be drawn between the environmental impacts of new developments, management, and renovation and restructuring. These three categories are often difficult to disentangle and tend to vary in size over time.

The environmental impacts of residential properties also depend on the behaviour of management agents, property owners, and occupants. This is related to the development of and the differences between lifestyles, the impact of tax policies, and economic trends. In a booming economy, the occupation rate of the housing stock declines because of the decrease in the size of households (Ermisch, 1983). As a result, housing consumption increases, pushing up the consumption of energy and nonrenewable materials. The uncoupling of economic growth from environmental damage is still a long way off as a feasible policy goal. The development of lifestyles can support or impede sustainable housing.

There are, in addition, quite a lot of contradictions in government policies. On the one hand, the government wants to promote sustainability, while on the other, it stimulates larger size homes with higher ceilings and a lower housing density. In the second half of the 1990s national and local governments in the Netherlands set their sights on a housing differentiation with a higher than ever share of one-family homes. These market-led developments have almost certainly reduced the sustainability of housing. The same applies for the fiscal support for homeowners and the housing allowances for tenants, which stimulate housing consumption and considerably reduce the sustainability of housing.

We can only conclude that the policy mix of the Dutch government has both stimulated and impeded sustainability. The net impact is not known: probably it is fairly negative. The best strategy to increase the sustainability of housing is not to build, and to reduce the housing consumption of the population. This has certainly not happened in the Netherlands, or in any other European country.

\section{Policy recommendations: how to cope with institutional barriers?}

\subsection{Introduction}

Governments are faced with a gap between conceptual and realised policy. Even though a need exists for more valid knowledge on the factors and conditions that determine sustainable development and sustainable housing, there is still enough reason to provide more stimulation for sustainable housing. Many practical barriers need to be overcome to achieve this.

\subsection{Splintered structure of building and real-estate sector}

Various observers report that, for a large part, institutional barriers and obstacles are now standing in the way of sustainable-housing development and management. Priemus et al (1999) argue that there are two main problems: inadequate ecological 


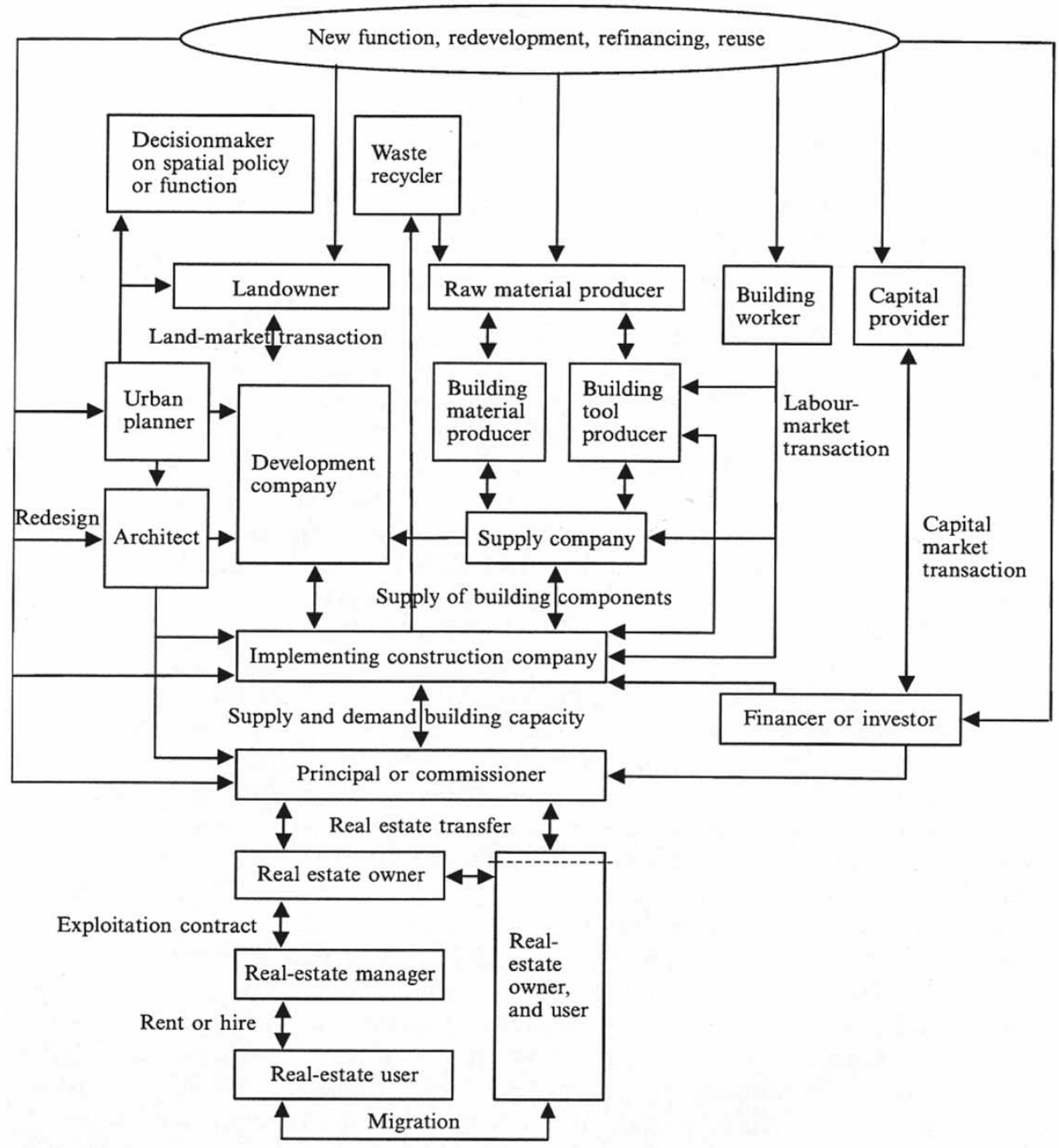

Figure 7. The construction and real-estate sectors: organisations and markets (source: van Bueren and Priemus, 2002, page 79).

inducements in the taxation system, and the fragmentation of responsibility in the construction and real-estate sectors (van Bueren and Priemus, 2002). There are many roles in the construction and real-estate sectors, which are divided among a large number of organisations, as shown in figure 7.

The list includes players from public, private, and hybrid organisations, whose knowledge and expertise cover a wide range of disciplines: architecture, urban planning, structural engineering, planning, civil engineering, transport engineering, mechanical engineering, economics, and housing management. Each player acts on the basis of rules and codes which have been individually formulated for and by the relevant profession. The traditional, conservative character of the construction industry is well known (Pries, 1995), although architects and urban planners may be more open than most to new initiatives and innovations. Figure 7 further demonstrates that there are also several markets involved in the management of the built environment, and transactions in these markets are also subject to specific rules. The interactions and decisionmaking processes in the 
construction and real-estate sectors are, therefore, highly fragmented, involving several markets and players as well as several separate sets of rules. Rarely is there any central figure coordinating the relationships and interactions. The direction of activities tends to be decentralised, focused on specific interactions between players, who therefore perceive a dependence only on those with whom they have direct contact. They are not usually conscious of any interrelationship with other players at different levels or stages of the planning process.

\subsection{Institutions and the promotion of sustainable building}

The institutional structure of the construction sector, as outlined in the previous section, influences the decisions of players with regard to the use of sustainablebuilding measures. To be effective, such measures demand a thorough consideration of all aspects at the decisionmaking stage. The effectiveness of a sustainable-building measure can be greatly enhanced or, conversely, completely undermined by players' decisions at various points in the decisionmaking process. For example, measures at the construction level (which often emerge at a late stage of the decisionmaking process) may well impose conditions in terms of urban planning. Similarly, benefits in terms of sustainability which can be achieved through urban planning measures may be undermined by certain decisions taken at lower levels. The institutional barriers identified in this paper represent 'gaps' between interactions and decisions at various points in the process of construction and management. They are points at which the relevant processes fail to converge.

In the following a number of dominant gaps are identified between various points in the decisionmaking process as examples of those engendered by the current institutional structure. Such gaps stand in the way of the players' ability to apply any thorough consideration to decisions regarding sustainable-building measures. I then move on to discuss the consequences of these gaps in terms of the cost-benefit analysis which is applied to the use of sustainability measures, an assessment which is of critical importance to all such decisions. Inevitably, where the distribution of pros and cons among the players is regarded as uneven, it will be impossible to arrive at any balanced decision as to whether or not to apply the measures at all.

\subsection{Gap between location development and building-project development}

An example of a gap in the decisionmaking processes can be found between location (area or site) development and building-project development. In location development the urban planning structure has already been determined, and includes the building density and the infrastructures for transport, water, energy, and waste. In such structures many opportunities for environmental gains can be created, with a view to allowing other parties to benefit in the later phases. However, one problem is that the players involved in location development are often unaware of their own ability to create environmental opportunities. For example, the energy infrastructure will determine the type of energy that will be distributed for many years to come, and the road infrastructure influences future mobility and the need for private car ownership. Even where due attention is devoted to such issues, helping to create favourable conditions for future environmental gains, others often fail to make good use of them when the time comes.

\subsection{Gap between construction and management}

Another prominent gap is discernible between construction and management. Players allow their decisions to be swayed by the objectives and interests arising from their involvement in the process. The building contractor is primarily concerned with delivering a product which meets legal requirements and which satisfies the demands of the principal, drawing on current knowledge and expertise where possible. 
Considerations which affect the management phase usually have little or no bearing on design or construction. This gap between building and management may manifest itself between the project developer and the (future) owner-occupier, or between the project developer and the investor. Even where construction and management are in the same hands, it may prove impossible to reconcile differences within one and the same organisation. For example, a housing association may well have separate departments to oversee construction and management activities. Each department will have its own set of goals, and it is not inconceivable that the goals of one will be irreconcilable with those of the other.

\subsection{Gap between construction and use}

It is the user - the future occupant - who will be most affected by the gap between construction and use. Many sustainability measures require some modification of user behaviour, with potential gains relying on the user's willingness to adopt new attitudes and practices. For example, some water-recycling systems require a certain discipline on the part of householders: not all waste water can be allowed to go straight down the plug hole! Another example is the well-insulated home in which residents have to remember not to turn on the central heating or the air conditioning with the window wide open. Research has shown that residents in sustainable-building projects have so far failed to adapt their behaviour sufficiently, whereupon they often thwart the efforts of architects and builders to counter negative environmental impact (Hertz, 1996). The rebound effect implies that, for a large part, behavioural reactions cancel out the impact of sustainable-housing measures.

\subsection{Asymmetric distribution of pros and cons}

The gaps in the decisionmaking processes in the building and real-estate sectors are the underlying reason why responsibility for the pros and cons of sustainable-building measures must be assigned to certain players in the building process. Cost savings and innovations may go together (Construction Industry Council, 2000) but energy-saving measures usually yield a financial advantage for the user, whereas the investment usually has to be made by the developer or the manager. The yields from these measures are uncertain because of fluctuations in the price of energy, the unknown potential of the measure itself, and the influence of the user's own behaviour. Given this uncertainty regarding the yield (that is, the extent of the benefits), the costs of such measures cannot be passed on to the user-at least not entirely. A further consideration for housing associations is that they must strive to ensure that rents remain within the means of the target group (and the limits imposed by legislation). Energy-saving measures may be unprofitable for the landlord from a strictly business point of view.

\subsection{Recommendations}

Many papers have been written on sustainable building and sustainable housing. Many of these present a set of recommendations. This paper is no exception.

First, empirical measurement may be regarded as the key to success. The 'Ecoquantum' program is a tried-and-tested instrument for measuring the environmental impact of a building. This method should be further improved and systematically implemented in drawing a comparison between alternatives. The validity and reliability of the method must be subject to ongoing scrutiny.

Second, ecological and environmental qualities must be combined with essential and familiar qualities, such as addressing the demand-driven market, flexibility, affordability, and technical reliability. If ecological quality were to subsume these other qualities, disappointment will surely result. 
Third, it is important to provide ongoing feedback to the users of a property with regard to their consumption of gas, electricity, and water. The meters must not be hidden in a meter box, out of sight and out of mind. The occupant should be confronted with the energy costs and the broader environmental impact of his behaviour on a daily basis. 'Domotics' (domestic automation) may assist in reducing environmental impact.

Fourth, we must avoid the 'pennywise, pound foolish' outlook. It is, and will remain, relevant to compare the costs of the various strategies designed to reduce negative environmental impact. It is also extremely important to press ahead with true 'breakthrough' development, such as that intended to usher in the hydrogen economy.

Fifth, priority must be given to an international policy approach, such as the Kyoto Agreement, and at least to an intensive European harmonisation and coordination of policy. In this respect much could be improved (Sunikka, 2001).

Sixth, we must continue to monitor the impact of prices and be aware of the extent to which certain subsidies can increase consumption. There are good arguments for the reduction or outright abolition of land and property purchase subsidies (van Driel, 1993; Priemus, 1993), and the other side of the equation - the regulating levies which make the price of energy and mobility higher - should also be adjusted. The higher the cost of energy, the sooner sustainable energy will be introduced on any large scale. It is regrettable that the Dutch government recently abandoned the idea of road pricing, despite the potential of this instrument for improving the sustainability of urban areas. Where the former Prime Minister, Wim Kok, espoused the introduction of a small levy, known popularly as 'the Kok Quarter', his successor would do well to introduce the 'Balkenende Buck' to foster the development of sustainable infrastructure and urban planning.

\section{Concluding remarks: towards a research agenda on sustainable housing}

Returning to the analogy with the emperor's new clothes, we have to conclude that when we try to evaluate government policy to promote sustainable housing in the Netherlands, the emperor is well and truly naked. First of all, sustainable housing is so broadly defined in many policy documents and academic publications that it covers almost everything. It is, then, more or less equivalent to 'good housing'. There are no indications whatsoever of how the sustainability of housing could be measured. Moreover, scarcely any distinction is drawn between the sustainability of housing development, management, use, and renovation/restructuring. No attempts are made to suggest a standard for measuring sustainability or environmental impact. As there is no zero line, there is no way of assessing the impact of a policy to promote sustainability. Some aspects of housing policy - the promotion of large dwellings, higher ceilings, owner-occupation - and some aspects of other policy (tax relief for owner-occupiers, stimulation of economic growth) adversely affect the environmental impacts of housing. National and local policy on sustainable housing appears to be 'all talk and no action'.

It would be fine if scientific researchers were to fill the policy vacuum in a responsible manner. This has been argued earlier by Bhatti et al (1994) in their publication Housing and the Environment: A New Agenda. The following priorities can be put forward for the sustainable housing research agenda:

(a) draw up a clear and sharp definition of sustainable housing and the environmental impact of housing;

(b) identify the operational variables that can best be used and how they should be measured; 
(c) make a sharp distinction between the environmental impacts of developing new dwellings, management, use, and renovation/restructuring of the housing stock, and the housing environment;

(d) determine the environmental impact of housing ex ante and compare it with measurements ex post;

(e) evaluate ex ante and ex post the environmental impacts of housing policies and some nonhousing policies;

(f) evaluate ex ante and ex post the main factors and developments, determining the environmental impact of housing - including the garden (Bhatti and Church, 2004): economy, household, income, energy prices, traffic mobility, residential mobility, etc;

(g) evaluate and measure rebound effects in the behaviour of occupants and housing managers which could reduce the positive impacts of environmental policies;

(h) evaluate and measure the unequal distribution of environmental problems: the issue of environmental justice (Bhatti and Dixon, 2003; Bullard, 1999).

The scientists, politicians, and practitioners still have a long way to go. In the meantime, I recommend that it is better to acknowledge that we do not know essential things about housing sustainability - rather than simply 'believing' in it.

\section{References}

Beerepoot M, 2002 Energy Regulations for New Building: In Search of Harmonization in the European Union (Delft University Press, Delft)

BEICT, 2002, "State of the Environment Report Card" Built Environment Innovation and Construction Technology number 24, April http://www.cmit.csiro.au/innovation/2002-04/soe3.htm

Bhatti M, 2001, "Housing/futures? The challenge from environmentalism" Housing Studies 16 $39-52$

Bhatti M, Church A, 2004, "Home, the culture of nature and meanings of gardens in late modernity" Housing Studies 1937 - 51

Bhatti M, Dixon A, 2003, "Introduction to the special focus: housing, environment, and sustainability” Housing Studies 18501 - 504

Bhatti M , Brooke J, Gibson M (Eds), 1994 Housing and the Environment: A New Agenda (Chartered Institute of Housing, Octavia House, Westwood Way, Coventry CV4 8JP)

Blaauw, K, 2001 Duurzame woningbouw in perspectief [Sustainable housing construction in perspective] (Delft University Press, Delft)

Bullard B, 1999, "Environmental justice" Local Environment 4 5-14

CBS, RIVM, 1999, Milieucompendium 1999: het milieu in cijfers [Environmental compendium 1999: the environment in statistics], Centraal Bureau voorde Statistiek, Voorburg

Construction Industry Council, 2000 The Role of Cost-saving Innovations in PFI Projects (Thomas Telford, London)

Curwell S, Cooper I (Eds), 1998, "The implication of urban sustainability" Building Research and Information $2617-28$

Dicke D, 2000 Aansluitende milieuzorg in de praktijk: Voordelen van een systematische aanpak van duurzaam bouwen van initiatief tot sloop [Seemless environmental management in practice: advantages of a systematic approach to sustainable building from initiative to demolition] (Aeneas, Best)

Dommen E, 1993 Fair Principles for Sustainable Development: Essays on Environmental Policy and Developing Countries (Edward Elgar, Cheltenham, Glos)

Duijvestein K, 1997, "Ecologisch bouwen" [Ecological construction], Delft University of Technology, Bk, SOM, Delft, lecture notes

ECN, 2000 Energie Markt Trends 2000 [Energy market trends] (ECN, Petten)

Ermisch J, 1983 The Political Economy of Demographic Change (Heineman, London)

Guinée J B, Gorree M, Heijungs R, Huppes G, Klein R, de Koning A, van Oers L, Wegener Sleeswijk A, Sangwon S, Udo de Haes H A, de Bruijn H, van Duin R, Huijbregts H A J, 2002 Handbook on Life Cycle Assessment: An Operational Guide to the ISO Standards (Kluwer Academic, Dordrecht)

Hasselaar E, 2001 Hoe gezond is de Nederlandse woning? [How healthy is the Dutch home?] (Delft University Press, Delft) 
Hatfield Dodds S, 2000, "Pathways and paradigms for sustaining human communities", in Sustaining Human Settlement: A Challenge for the New Millennium Ed. R J Lawrence (The Urban International Press, North Shields) pp $28-54$

Hertz B, 1996, "Bewonersgedrag in Duurzaam Bouwen Projecten" [Resident behaviour in sustainable building projects] Milieu $4161-169$

ISO, 1997, International Organization for Standardization, Environmental Management - Principles and Framework ISO 14040: 1997, Geneva

Klunder G, 2000 Milieuanalyse van de woningbouw: Speerpunten voor vermindering van de milieubelasting [Environmental analysis of housing: spearheads for the reduction of environmental impact] internal publication, OTB Research Institute for Housing, Delft University of Technology, Delft

Klunder G, 2002a Hoe milieuvriendelijk is duurzaam bouwen? De milieubelasting van woningen gekwantificeerd [How environment friendly is sustainable building? The environmental burden of housing quantified] (DUP Science, Delft)

Klunder G, 2002b "The search for the most eco-efficient strategies for sustainable housing construction", internal publication, OTB Research Institute for Housing, Delft University of Technology, Delft

Kruythoff H M, Haars A, 2002 Herdifferentiatie van de woningvoorraad: Inventarisatie Meerjarenontwikkelingsprogramma's $G 30$ [Redifferentiation of the housing stock: an inventory of G30 long-term development programmes] (Delft University Press, Delft)

Kuik O, Verbruggen H (Eds), 1991 In Search of Indicators of Sustainable Development (Kluwer, Dordrecht)

Lawrence R J (Ed.), 2000 Sustaining Human Settlement: A Challenge for the New Millennium (The Urban International Press, North Shields)

McMichael A, 1993 Planetary Overload: Global Environmental Change and the Health of the Human Species (Cambridge University Press, Cambridge)

Ministry of Housing, Spatial Planning and the Environment, 1997 Tweede plan van aanpak duurzaam bouwen [Second action plan for sustainable building], The Hague

Mitchell G, 2000, "Indicators as tools to guide progress on the sustainable development pathways", in Sustaining Human Settlement. A Challenge for the New Millennium Ed. R J Lawrence (The Urban International Press, North Shields) pp 55-104

Novem, 1998 Energieneutraal bouwen. programma Lange Termijn Onderzoek Gebouwde Omgeving $1997-2001$ [Energy neutral construction: long-term research programme for the built-up environment] Novem, Catharijnesingel 59, 3511 GG Utrecht

Novem, Boom, 2000 Vademecum energiebewust ontwerpen van nieuwbouwwoningen [A guide to the energy-conscious design of new residential property] Novem, Catharijnesingel 59, 3511 GG Utrecht

Polèse M, Stren R (Eds), 2000 The Social Sustainability of Cities: Diversity and the Management of Change (University of Toronto Press, Toronto)

Priemus H, 1993, "Over duurzaam (ver)bouwen en wonen en de zorg voor zwakkeren" [On sustainable (re)construction, home-making and care for the vulnerable], in Milieubeleid en consumptiepatronen [Environmental Policy and Patterns of Consumption] Ed. P van Driel (Wiardi Beckman Foundation, Amsterdam) pp 71 - 81

Priemus H, van Bueren E, Blaauw K, Hasselaar E, Klunder G, Veentjer M, 1999 Institutionele belemmeringen voor factor 20 bij de besluitvorming over duurzaam bouwen [Institutional obstacles relating to factor 20 in the decision-making procedures for sustainable building] (Delft University Press, Delft)

Pries F, 1995 Innovatie in de bouwnijverheid [Innovation in the construction industry] (Eburon, Delft)

Quist H J, van den Broeke R A, 1994 Duurzaamheid en het beheer van de woningvoorraad [Sustainability and the management of the housing stock] (Delft University Press, Delft)

Redclift M, 1989 Sustainable Development, Exploring the Contradictions (Routledge, New York)

Rotmans J, 2003 Transitiemanagement: sleutel voor een duurzame samenleving [Transition management: key for a sustainable society] (Van Gorcum, Assen)

Sheridan L (Ed.), 2001 The Control and Promotion of Housing Quality in Europe. Part I. Country Monographs, Part II. Comparative Analysis (Delft University Press, Delft)

Sunikka M, 2001 Policies and Regulations for Sustainable Building. A Comparative Study of Five European Countries (Delft University Press, Delft)

Sunikka M, Boon C, 2002 Housing Associations and Sustainable Management. Environmental Efforts in The Netherlands' Social Housing Sector (Delft University Press, Delft) 
van Arkel W G, Jeenings H, Menkveld M, Ruig G J, 1999 Energiegebruik van gebouwgebonden energiefuncties in woningen en utiliteitsgebouwen [The energy consumption of building-related energy functions of residential and non-residential property], ECN, PO Box 1, 1755 ZG Petten

van Bueren E M, Priemus H, 2002, "Institutional barriers to sustainable construction"

Environment and Planning B: Planning and Design 29 75-86

van Driel P (Ed.), 1993 Milieubeleid en consumptiepatronen [Environmental policy and patterns of consumption], Wiardi Beckman Foundation, Postbus 1310, 1000BH Amsterdam

van Kempen R, Priemus H (Eds), 1999 Stadswijken en herstructurering [Urban districts and restructuring] (Van Gorcum, Assen)

Wackernagel N, Rees W E, 1996 Our Ecological Footprint: Reducing Human Impact on the Earth (New Society Publishers, Gabriola Island, BC)

World Commission on Environment and Development (Brundtland-Commission), 1987 Our Common Future (Oxford University Press, Oxford) 
